\begin{tabular}{|c|c|c|c|c|c|c|}
\hline \multirow{4}{*}{ Impact Factor: } & ISRA (India) & $=3.117$ & SIS (USA) & $=0.912$ & ICV (Poland) & $=6.630$ \\
\hline & ISI (Dubai, UAE & $=0.829$ & РИНЦ (Russia & $=0.156$ & PIF (India) & $=1.940$ \\
\hline & GIF (Australia) & $=0.564$ & ESJI (KZ) & $=8.716$ & IBI (India) & $=4.260$ \\
\hline & JIF & $=1.500$ & SJIF (Morocco & $=\mathbf{5 . 6 6 7}$ & OAJI (USA) & $=0.350$ \\
\hline
\end{tabular}

\begin{tabular}{|c|c|}
\hline $\begin{array}{l}\text { SOI: } \underline{1.1 / \mathrm{TA}} \\
\text { International Sc } \\
\text { Theoretical } \mathbf{\&} \mathbf{A}\end{array}$ & $\begin{array}{l}\text { S DOI: } 10.15863 / \mathrm{TAS} \\
\text { ientific Journal } \\
\text { pplied Science }\end{array}$ \\
\hline p-ISSN: 2308-4944 (print) & e-ISSN: 2409-0085 (online) \\
\hline Year: 2019 Issue: 03 & Volume: 71 \\
\hline Published: 23.03 .2019 & \\
\hline
\end{tabular}

SECTION 7. Mechanics and machine construction.
QR - Issue

QR - Article
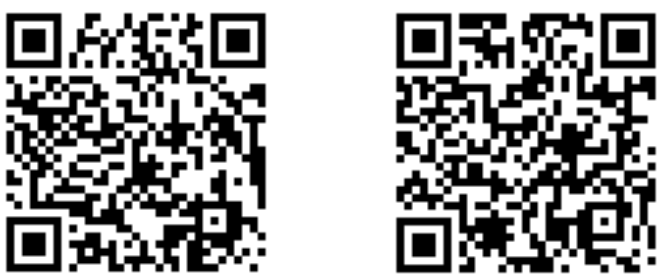

Denis Chemezov

M.Sc.Eng., Corresponding Member of International Academy of Theoretical and Applied Sciences, Lecturer of Vladimir Industrial College, Russian Federation https://orcid.org/0000-0002-2747-552X chemezov-da@yandex.ru

Alexey Averyanov Student of Vladimir Industrial College, Russian Federation

Irina Pavluhina Lecturer of Vladimir Industrial College, Russian Federation

Ilya Filippov Student of Vladimir Industrial College, Russian Federation

Maxim Potapov Student of Vladimir Industrial College, Russian Federation

Elena Kiseleva Master of Industrial Training, Vladimir Industrial College, Russian Federation

\title{
RESEARCH OF CASTINGS STRUCTURES MADE OF MIM 4140 BEFORE AND AFTER HEAT TREATMENT
} article.

Key words: a casting, structure, injection molding, heat treatment.

Language: English

Citation: Chemezov, D., Averyanov, A., Pavluhina, I., Filippov, I., Potapov, M., \& Kiseleva, E. (2019). Research of castings structures made of MIM 4140 before and after heat treatment. ISJ Theoretical \& Applied Science, 03 (71), 368-371.

Soi: http://s-o-i.org/1.1/TAS-03-71-27 Doi: croskef https://dx.doi.org/10.15863/TAS.2019.03.71.27

\section{Introduction}

Modern production technologies allow to obtain with high performance and accuracy (at low surfaces roughness) metal parts of a complex shape. Metal injection molding (MIM) is one of the modern technologies of the metal products manufacturing. This technology includes the several stages: mixing of metal powder with polymer binder, injection molding of mixture, removing of polymer binder, a casting sintering in a furnace to obtain of the physical and mechanical properties of the finished part $[1-10]$. The finished part has high density and crack resistance. A structure analysis of the semi-finished product material and the finished part was carried out on the example of manufacturing of the part "Plunger" (the element of a combat pistol) by the MIM technology. 


\begin{tabular}{|c|c|c|c|c|c|c|}
\hline \multirow{4}{*}{ Impact Factor: } & ISRA (India) & $=3.117$ & SIS (USA) & $=0.912$ & ICV (Poland) & $=6.630$ \\
\hline & ISI (Dubai, UAE & $=0.829$ & РИНЦ (Russia) & $=0.156$ & PIF (India) & $=1.940$ \\
\hline & GIF (Australia) & $=0.564$ & ESJI (KZ) & $=8.716$ & IBI (India) & $=4.260$ \\
\hline & JIF & $=1.500$ & SJIF (Morocco) & $=5.667$ & OAJI (USA) & $=0.350$ \\
\hline
\end{tabular}

\section{Materials and methods}

MIM 4140 (alloy) was subjected to injection molding. Molding temperature of eight castings in a mold was $180^{\circ} \mathrm{C}$. Pressure at injection molding was taken in the range of $1000-1700 \mathrm{~kg} / \mathrm{cm}^{2}$. Alloy was subjected to downtime under pressure for the duration of 3 seconds after the filling process. The molding cycle of the castings lasted from 35 to 60 seconds. The casting process was carried out at cooling liquid temperature of $40-60^{\circ} \mathrm{C}$. Calculated mass of one casting was $1.1 \mathrm{~g}$. The equipment and the tooling for injection molding are presented in the Fig. 1.

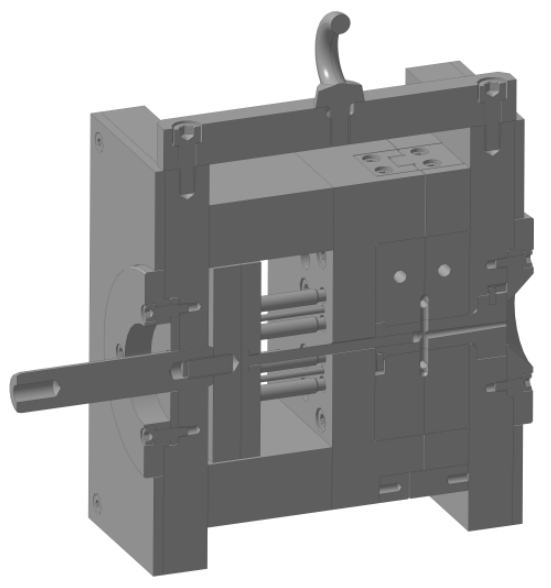

A

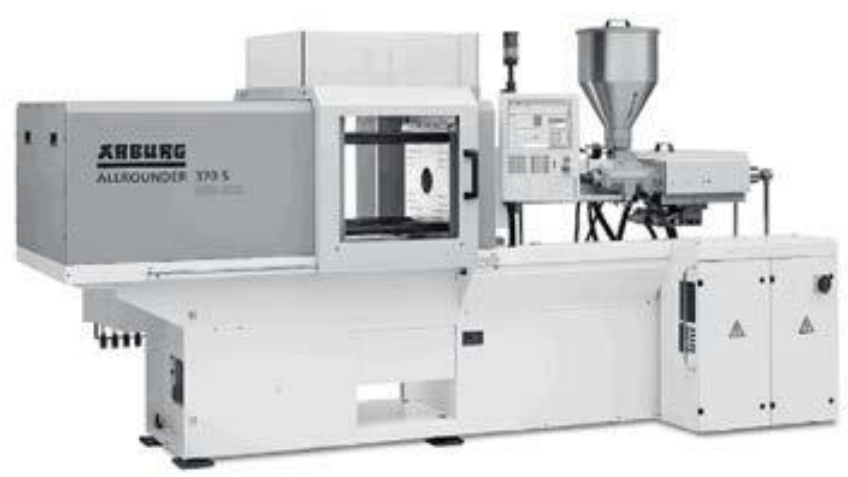

B

Figure 1 - The mold model for injection molding (A) and the injection molding machine "Arburg Allrounder" (B).

Shrinkage of polymer material in the molding process of the part was $18 \%$. The castings made of MIM 4140 before heat treatment (after injection molding) and after heat treatment (after sintering) are presented in the Fig. 2. The castings were cut into two parts (with a knife and on the electrical-discharge machine) for considering of material structure on the side walls and the bottom.

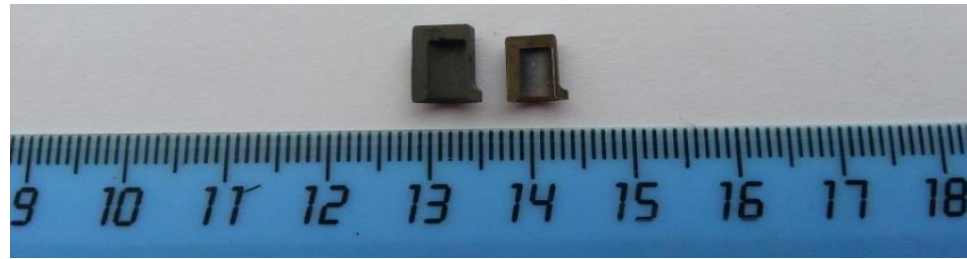

Figure 2 - The castings before heat treatment (left) and after heat treatment (right).

The structure research of MIM 4140 before and after heat treatment was realized on the digital inverted metallographic microscope "RAZTEK MRX9". Capture and save of the images of alloy structure were carried out with the digital camera

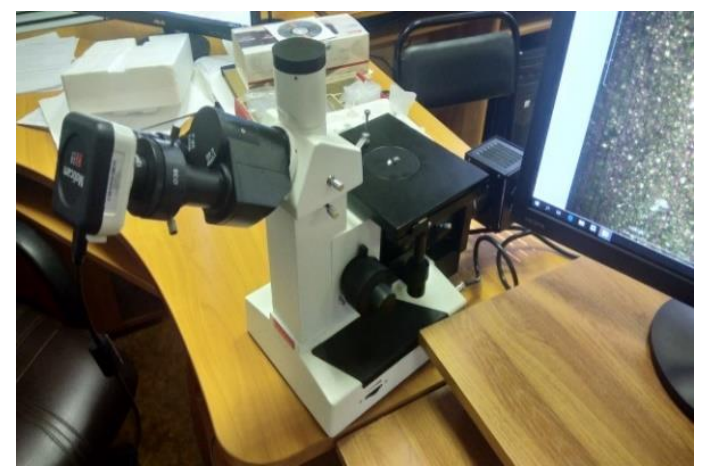

A
"Moticam" (2 mp). The castings structures were researched at magnification of 400 times. The equipment for realization of the research and the installation scheme of the casting on the microscope stage are presented in the Fig. 3.

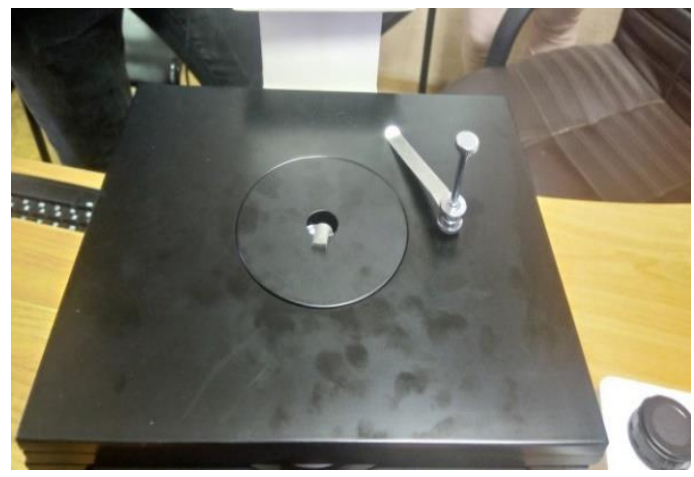

B

Figure 3 - The equipment for realization of the research: A - general view of the metallographic microscope; B - the microscope stage with the installed casting. 


\begin{tabular}{|c|c|c|c|c|c|c|}
\hline \multirow{4}{*}{ Impact Factor: } & ISRA (India) & $=3.117$ & SIS (USA) & $=0.912$ & ICV (Poland) & $=6.630$ \\
\hline & ISI (Dubai, UAE & $=0.829$ & РИНЦ (Russia) & $=0.156$ & PIF (India) & $=1.940$ \\
\hline & GIF (Australia) & $=0.564$ & ESJI (KZ) & $=8.716$ & IBI (India) & $=4.260$ \\
\hline & JIF & $=1.500$ & SJIF (Morocco & $=5.667$ & OAJI (USA) & $=0.350$ \\
\hline
\end{tabular}

\section{Results and discussion}

The castings structures made of MIM 4140 before and after heat treatment are presented in the Fig. 4. These structures were considered on a cut surface of the side wall.

The casting structure before heat treatment is uniform. Inclusions of the binder component (the white elements) were distributed throughout the casting volume. This suggests that the semi-finished product obtained by injection molding has the same mechanical properties throughout the volume. The binder component has different dimensions on the cut

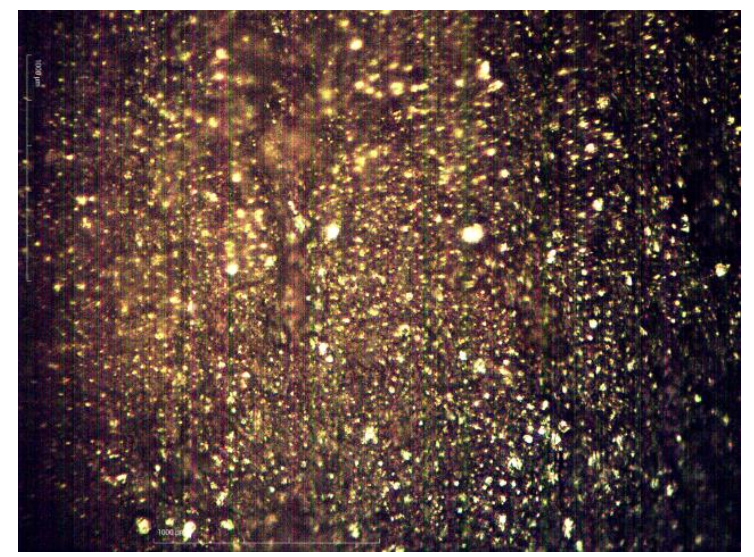

A surface of the casting. Defects on the cut surface of the casting are accidental crumbling of alloy at cutting.

The binder component is removed from alloy after heat treatment (sintering) in the furnace. Received structure of the part is homogeneous. Removing of the binder component leads to pores formation in the part material. The casting volume decreases, and material strength increases to the required value indicated on the working drawing and in the documents set for the technological process of manufacturing of the part "Plunger". The pores dimensions after sintering of the casting are $0.1-0.25$ $\mathrm{mm}$.

Figure 4 - Structures of MIM 4140 at magnification of 400 times: A - the semi-finished product before heat treatment, $\mathrm{B}$ - the part after heat treatment.

\section{Conclusion}

So as casting is carried out under pressure then structure density of the semi-finished product after cooling is high. This leads to uniform distribution of metal powder and polymer binder in the casting volume. The binder component is removed during heat treatment (the semi-finished product shrinkage). Further processing of the part "Plunger" after sintering is not required. This combined method is rationally used for manufacturing of the complex miniature metal and ceramic parts.

\section{References:}

1. Chemezov, D. (2018). Properties of MIM 4140 Alloy after Injection Molding and Sintering. International Journal of Innovation Engineering and Science Research, Volume 2, Issue 1, 10-14.

2. Chemezov, D., Kononov, D., Molkov, A., Smirnova, L., \& Bogomolova, E. (2018). Computer and laboratory research of condition of MIM 4140 alloy after injection molding and sintering. International Journal of Innovation Engineering and Science Research, Volume 2, Issue 3, 27-35.

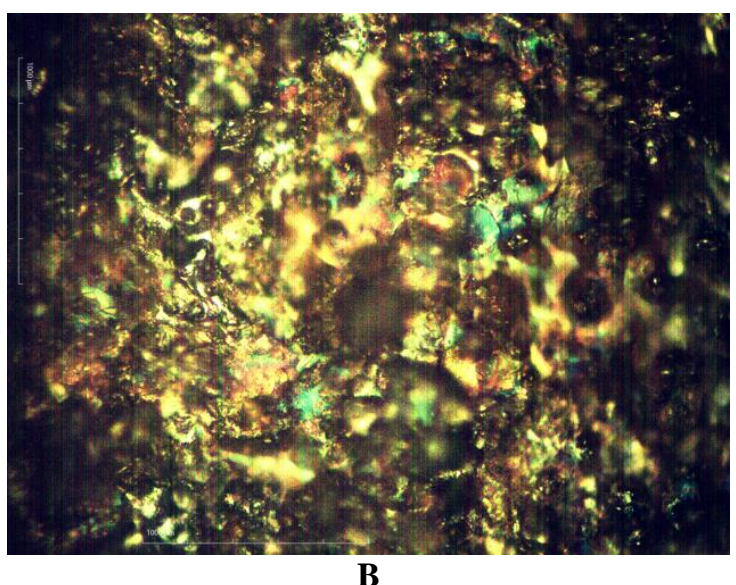

B

\section{e).}




\begin{tabular}{|c|c|c|c|c|c|c|}
\hline \multirow{4}{*}{ Impact Factor: } & ISRA (India) & $=3.117$ & SIS (USA) & $=0.912$ & ICV (Poland) & $=6.630$ \\
\hline & ISI (Dubai, UAE & $=0.829$ & РИНЦ (Russia & $=0.156$ & PIF (India) & $=1.940$ \\
\hline & GIF (Australia) & $=0.564$ & ESJI (KZ) & $=8.716$ & IBI (India) & $=4.260$ \\
\hline & JIF & $=1.500$ & SJIF (Morocco & $=5.667$ & OAJI (USA) & $=0.350$ \\
\hline
\end{tabular}

automotive industry. PIM International, Vol. 9, No. 4, 33-47.

6. Heaney, D. (2012). Handbook of metal injection molding. Woodhead Publishing Ltd, 586 p.

7. German, R. M., \& Bose, A. (1997). Injection molding of metals and ceramics. Princeton (New Jersy, USA): MPIP.

8. Fngelo, H. C., \& Subramanian, R. (2009). Powder Metalurge: Science, technology and application. Published by Asoke K. Ghosh, PHI Learning Privated Limited, M-97, Connaught
Circus, New Dehli-110001 and Printed by Jay Print Pack Private Limited, New Dehli-110015.

9. Ye, H., Liu, X. Y., \& Hong, H. (2008). Fabrication of metal matrix composites by metal injection molding - A review. Journal of materials processing technology, 12-24.

10. Mathew, B. A., \& Mastromatteo, R. (2002). Metal injection molding for automotive applications. Metal Powder Report, Volume 57, Issue 3, 20-23. 